\title{
Does Vote Buying Affect Voting Behaviour? Chasing Winning Margins and the Prisoner's Dilemma
}

Making vote buying work is extraordinarily difficult, especially in the presence of ballot secrecy. Yet vote buying is extremely widespread in Indonesian electoral politics. Furthermore, vote-buying efforts face serious problems in their targeting: as we have seen, political actors try to 'buy' the votes of those who look like their loyal supporters, yet in practice end up giving most payments to other voters. The problems get worse as a result of rent-seeking behaviours by brokers, which increase the inefficiency of vote buying. All this leads to an obvious puzzle: if such electoral handouts are so misdirected and create strong incentives for brokers to extract rents, why do candidates invest so much money and goods in them? The answer must be found at least partly in the effect of vote buying on electoral behaviour. How effective is vote buying in actually winning votes? Surely it must have some effect in order for candidates to pursue it?

Little research has been conducted in Indonesia to measure the influence of vote buying on voting behaviour. In the beginning part of this chapter, I endeavour to quantify the impact of vote buying on voter turnout and the vote shares won by candidates. I find that handouts actually produce a sizeable turnout or higher vote share for the distributing candidate. However, I also find payments influences decisively the votes of 'only' about $10 \%$ of people who receive them. In this seemingly low number lies the key to the attractiveness of a vote-buying strategy. The proportion of recipients who admit their choice is influenced by material 
inducements is more than enough to constitute a small margin of victory for most candidates.

However, chasing small margins isn't the whole answer for why candidates buy votes. There are many countries and elections where the vote margins are small, and still candidates don't engage in vote buying. Accordingly, I would argue that even if the returns are so poor, and even if candidates aren't running in a close battle, they still engage in buying votes in the presence of rampant handout distribution by their competitors towards the responsive voters in the run-up to the election. Even so, it is widely assumed among political machines that although vote buying may be an objectively inefficient strategy for generating votes, it is still more efficient than all other viable alternatives.

\subsection{EfFect on Voter Turnout}

As its name implies, vote buying is often defined in the literature as a direct market transaction where voters provide their vote in return for money or gifts (Guardado and Wantchekon, 2014). Brusco and her collaborators (2004: 67), for instance, define vote buying "as the proffering to voters of cash or (more commonly) minor consumption goods by political parties, in office or in opposition, in exchange for the recipient's vote." In a similar vein, Finan and Schechter (2012: 864) view vote buying as "[offered] goods to specific individuals before an election in exchange for their votes." Given that vote buyers often don't explicitly demand a vote in exchange for their payment, Aspinall and Sukmajati (2016: 20) slightly modify the definition as "the systematic distribution of cash payments and/or goods to voters in the few days leading up to the election with the implicit expectation that recipients will repay with their vote." Similarly, Kramon (2009: 4) defines vote buying as "the distribution of particularistic or private material benefits with the expectation of political support." All of these definitions assume that paying boosts voter turnout and/or the vote share of the paying candidate or party (Guardado and Wantchekon, 2014: 2).

In practice, however, vote buying is an uncertain business. How do vote buyers ensure that the vote that is being sold is actually provided, especially in the presence of ballot secrecy? As previously presented in Chap. 6, most electoral payoffs in Indonesia are provided before the elections. If this is the case, it is possible for the recipients to behave opportunistically: to take the money and run. But if a candidate was to promise to provide cash only after the election, voters would likely suspect that the candidate would break his/her promise and not deliver (Baldwin, 2016: 67). 
If vote buying instead takes place before the election, with voters accepting payment but still being allowed to vote based upon their conscience, as Kramon (2009: 2) has questioned, why might vote buying have an influence on voting behaviour?

The effectiveness of vote buying clearly relates to the party loyalist versus swing targeting debate in the literature. If we stick with the party loyalist argument, which views vote buying as turnout buying in which parties or candidates target voters who are already inclined to support them, the payment looks more like the mobilisation of passive supporters to come to the voting booth rather than 'buying' the vote of an indifferent voter. In contrast, the swing-voter hypothesis implies that the payment really does act to purchase the support of an uncommitted voter. In this case, monitoring whether recipients turn out at the polls is less of an issue for the distributing party than is monitoring vote choice (Nichter, 2008). In the turnout-buying model, if a passive supporter bothers to turn out, the givers can be confident that the voter will choose them. This sharply contrasts with the model presented by the swing-voter school, ${ }^{1}$ under which even if the recipient shows up at the polls, the vote buyer will still have no guarantee whether that person votes for the buyer or some other candidate.

Regardless of such challenges, I argue that politicians still have incentives to pursue vote buying because the evidence suggests it seems to influence voting behaviour in Indonesia. Let us first discuss its impact on voter turnout. My survey of voters conducted immediately after the 2014 parliamentary election allows me to examine the effect of vote buying on turnout. While the measure of vote buying has been already discussed in Chap. 2, the wording for the question on turnout was: "When discussing the election with others, we found many people couldn't vote because they were far from home, sick, or didn't have the time or other reasons. What about you? Did you vote during the last legislative election on April 9,2014?" Given that social desirability bias might induce the respondents to overstate their voting histories, I weighted the reported turnout by using the official turnout rate according to Indonesia's General Election Commission (KPU). The commission reported that national turnout for the 2014 legislative election was about $75 \%$ (Table 7.1$){ }^{2}$

To test how voter turnout is affected by electoral handouts, I ran a cross-tabulation followed by chi-square to determine whether or not a null

\footnotetext{
${ }^{1}$ Abstract Politics. (2008)http://abstractpolitics.com/2008/05/vote-buying-or-turnoutbuying/.

${ }^{2}$ See http://www.kpu.go.id/koleksigambar/Partisipasi_Pemilih_pada_Pemilu_2014_ Studi_Penjajakan.pdf.
} 
Table 7.1 Cross-tabulation of a respondent's reported turnout and their likelihood of being offered vote buying (\%)

\begin{tabular}{lrlll}
\hline & & \multicolumn{2}{c}{$\begin{array}{c}\text { Did you vote during } \\
\text { the 2014 election? }\end{array}$} & Total \\
\cline { 2 - 3 } & & No & Yes & \\
\hline Receiving offers of vote buying in the & No & 26.0 & 74.0 & 100 \\
2014 legislative elections & Yes & 19.0 & 81.0 & 100 \\
Total & & 24.3 & 75.7 & 100 \\
Pearson chi-square (Value/df/significance) & & & $5.675 / 1 / 0.017$ \\
\hline
\end{tabular}

Source: My post-election survey, 22-26 April 2014

hypothesis can be rejected. The 'don't know' or 'refuse to answer' options weren't included in the analysis. My primary interest was to examine the hypothesis that respondents who were exposed to vote buying were more likely to participate in the 2014 elections. The cross-tabs seem to support the notion that electoral handouts are quite effective at producing a higher turnout. About $81 \%$ of the respondents who received a pre-electoral benefit showed up at the polls, compared to $74 \%$ of those who didn't receive offers of vote buying. Turning to the measures of strength and significance, the Pearson chi-squared value is 0.017 , meaning that it is below the $p$-level of 0.05 , thus making it significant. Although vote buying and voter turnout do have a statistically significant association, it is also reasonable to argue that vote buyers were targeting voters they believed or knew were more likely to vote. As argued in Chap. 2, this notion is in line with the evidence that candidates and brokers tend to target more heavily that group of voters for whom vote buying is an acceptable practice, which in turn increases their likelihood to vote if given rewards.

Overall, the findings provide initial suggestive evidence that vote buying may have a significant impact on turnout, but we cannot be sure about the direction of causation: it may be that success teams target for payment voters who they identify as being more likely to turn out.

\subsection{Effect on Vote Choice}

Having reviewed the effect of vote buying on voter turnout, we are now in a position to test its influence on voting choice. I return to data from my large nationally representative survey conducted immediately after the 
Table 7.2 Relative influence of vote buying between 2009 and 2014 (\%)

\begin{tabular}{llcc}
\hline Measure & Baseline & Influence & Total score \\
\hline Direct individual vote buying in 2014 & 25 & 41.8 & 10.2 \\
Direct individual vote buying in 2009 & 10.1 & 49.6 & 4.9 \\
\hline
\end{tabular}

Source: My post-election survey, 22-26 April 2014

2014 legislative election. The data allow me to quantify the effects of vote buying.

Table 7.2 provides a sense of comparison between reported vote buying and its effects on vote choice ${ }^{3}$ in the 2009 and 2014 legislative elections based on the direct individual questions. Recall that the question about the influence of vote buying was only asked to those who admitted being offered a reward. Of those subjects $(25 \%)$ who reported being targeted in 2014 , around $41.8 \%$ admitted that the handouts were effective at influencing their vote. Overall, then, my study finds evidence that vote buying produces electoral support for the distributing party or candidate. However, its effect seemed to be 'limited,' amounting to 'only' $10.2 \%$ of the total electorate.

\subsection{Chasing a Margin of Victory}

At first glance, the estimate I have come up with for the effect of vote buying may appear small, since the data showed that only a relatively small proportion of recipients of payments reciprocate with votes. These results present a puzzle. If this is true that vote buying yields minor results, why do politicians do it? If the votes of only a small proportion of those to whom they deliver payments are swayed, why do they persist? Note that vote buying isn't an easy task. The problems of broker predation and misdirected targeting already make vote buying tremendously inefficient, as discussed in earlier chapters. Yet on top of these problems, it is also, overall, ineffective at influencing vote choices. Under such circumstances, why do candidates invest large amounts in gifts to voters?

The answer is found in the high electoral uncertainty regarding candidates' personal prospects of victory. Although, the effect of vote buying

\footnotetext{
${ }^{3}$ If a respondent gave an affirmative reply when asked about vote-buying offers, I asked a follow-up question: "Did the gifts have an influence on your vote?"
} 
on electoral outcomes looks insignificant, a minor shift in votes can make a huge difference for a candidate. It can be the difference between winning and losing in a competitive election. Candidates have reason to invest in vote buying because they are usually chasing a narrow winning margin.

\subsubsection{Open-List PR and Electoral Competitiveness}

In order to substantiate this argument, I first establish the extent to which electoral competitiveness affects candidate behaviour. As discussed in Chap. 1 , since the introduction of a fully open-list system in 2009 , legislative elections have been extremely competitive. Note that in Indonesia's 2014 legislative elections, there were 6608 candidates distributed across 12 national parties running for the 560 seats in the House of Representatives. Therefore, the average level of competitiveness was 11.8 candidates per seat. As discussed in Chap. 1, in order to determine the winning candidate according to the open-list system, each party that successfully secures a seat (or seats) must allocate it (or them) to whichever of its candidates obtained the most votes. If there is only one seat for the party, the winner takes all. The open-list system has thus produced a pattern of 'ground war' electioneering in which candidates from the same party engage in intense campaigning for personal votes (Aspinall et al., 2017: 12). PDI-P's Richard Sualang, for instance, recalled that during the 2014 campaigns one candidate from a different party approached him to release his voter lists (the lists which, as we have seen, many candidates use to determine to whom they will deliver cash payments). If he was willing to hand over the lists, this external rival promised he would use them to ensure that he wasn't targeting Sualang's base voters, and to ensure that he was instead distributing resources to his own constituents in order to outspend his co-partisans (Interview, 26 April 2014).

As a result of this situation, legislative elections in Indonesia have become zero-sum games. One striking example is a close battle for a seat in the provincial legislature in the electoral district 5, Special Region of Yogyakarta. PDI-P was declared to be the winner and received two seats. Koeswanto won the first seat by a comfortable margin. However, there was great uncertainty about which candidate would secure the second seat because the results were so close. With $99 \%$ of the vote counted, it was still unclear who would win. Eventually, the final count gave incumbent candidate Gimmy Rusdin victory by a single vote, meaning that the vote margin 
was essentially zero. He won the race dramatically with a total of 9417 votes, while his internal rival, Listiani Warih Wulandari, secured 9416 votes. ${ }^{4}$

Under open ballot systems, candidates have clear incentives to compete against internal party rivals rather than focusing their competition against candidates from other parties. Whether based on past voting records or a strong belief that each party has its own constituency, they are usually able to predict how many seats each party will win in a given electoral district (Ibrahim, 2016), or at least there is relatively little uncertainty regarding the distribution of seats among parties. But they suffer from a high degree of uncertainty regarding which individual candidate will win. This is particularly the case when there is no candidate who is widely favoured to win in a particular district. Even the presence of a very popular candidate doesn't necessarily lower the level of uncertainty. In the electoral district Central Java V, it is almost impossible for PDI-P candidates to defeat the incumbent, Puan Maharani, the daughter of party matriarch Megawati Soekarnoputri. But although Puan regularly wins one seat, other candidates from the same party still have a chance of getting elected to the additional seats in the constituency.

The dominant narrative among candidates is that open-list PR systems offer a degree of hope of electoral success to all candidates as individuals, and that their electoral fate therefore depends heavily on their own efforts. Note that in order to gain a seat, candidates first need to make sure their party reaches the 2014 national threshold for parliamentary representation $(3.5 \%$ of the national vote) and reaches the quota required to gain at least one seat in their electoral district (this is the total number of valid votes cast in the electoral district divided by the total number of seats). The total vote for the party and its individual candidates is therefore important. Assuming a party gains one seat in a district, since that seat goes to the candidate on the party list who obtains the most personal votes, most elected candidates are helped by voters who vote either for the party only or for other candidates from the party. In short, the main challenge for candidates is to be ranked above their co-partisans. Hence, most candidates approach an election feeling they need to figure out how many personal votes they need to win, how close the race will be, who their main internal rivals are, their relative areas of strength, and so on.

\footnotetext{
${ }^{4}$ E-Parlemen DPRD DIY, “Daftar Caleg Terpilih DPRD DIY Periode 2014-2019,” 25 April 2014.
} 
The literature on electoral mobilisation shows that politicians act strategically. If they have little chance of getting elected, they don't invest large amounts of resources in personal campaigns. Likewise, if they have a reasonable chance of winning a seat, they will make more of an effort to compete (Milazzo and Karp, 2013). Selb and Lutz's important study (2015) found that the level of competitiveness isn't only determined by actual election results but also by candidates' self-perceived competitiveness. Candidates facing a narrow loss or narrow victory are likely to spend heavily in search of personal votes to outdo co-partisans, generating a cycle of competition which results in even more competitive elections.

This setting is clearly relevant to my inquiry into vote buying. The great uncertainty surrounding electoral outcomes in places like Indonesia creates incentives for candidates to pursue vote buying to maximise the chances of winning (Kitschelt and Wilkinson, 2007; van de Walle, 2007). The literature has long stated that vote buying tends to be higher in constituencies where elections are highly contested. ${ }^{5}$ The rationale is simple: in an environment in which a relatively small percentage of the votes can change candidates' electoral fortune, their propensity to engage in vote buying increases. In this regard, vote buying is a means of reducing electoral uncertainty (Jensen and Justesen, 2014). Electoral uncertainty is in fact the defining feature of electoral competitiveness (Przeworski, 1986; Schedler, 2013). The more uncertain the outcome of an election, the more competitive it is (Blais and Lago, 2009: 95; Franklin, 2004: 56-57). It follows that under an electoral system which creates competition for personal votes, candidates' uncertainty regarding the probability of winning will make them consider vote buying as a way to chase even a narrow margin of victory.

In this study, electoral competitiveness is measured at the national level and is operationalised as margin of victory. Using official election statistics, this chapter presents two different measures of the margin of victory-one taken as a percentage of overall valid votes in the electoral district and one as a percentage of the valid votes per party in the district. Note that this may be problematic when comparing to the effectiveness of vote buying: a single vote buyer doesn't distribute payments either to all voters in the electoral district, or even to all who support his or her party, but to a sig-

\footnotetext{
${ }^{5}$ Indeed, there is an issue of reverse causation here, which I will address in the final part of this chapter, whether candidates are more inclined to buy votes in more competitive districts or whether more vote buying makes districts more competitive.
} 
nificantly lower number. But, at least, the latter (i.e. a percentage of valid votes cast for a party in an electoral district) is a better measure for assessing the margins needed by individual candidates to win by distributing cash (remembering that no candidate will distribute cash to all the party's voters in an electoral district, let alone to all voters). Hence, my analytical focus is on victory margin as a percentage of the valid votes cast for each party in the district.

In this section, however, I start determining average margin of victory as a percentage of all valid votes cast in the constituency, simply to provide a broader picture of how competitive parliamentary elections in 2014 were in each constituency. However, given that under open ballot systems electoral competition takes the form of intraparty competition, and considering that under the system, the primary focus of candidates (the main vote buyers) is getting themselves a seat before their intraparty competitors, the level of competitiveness should be closely examined within political parties. Accordingly, after establishing the difference between the vote share of the lowest-placed winner and the highest-placed losing candidate from the same party in any electoral district, I will discuss the primary interest of this study: margin of victory as percentage of votes cast for a particular party in the constituency in the following section. Then, as I elaborate later in this chapter, in order to test the relationship between vote buying and such electoral competitiveness - measured as the margin of victory-I merge the actual election results with pre-electoral district surveys to gain ex-ante information on the ubiquity of vote buying at the constituency level.

Before proceeding, I present descriptive findings about the closeness of electoral results in each electoral district using victory margins of individual candidates over their party-list rivals as the primary measure of electoral competitiveness, with those victory margins calculated as a percentage of the total valid votes cast in the constituency. Figure 7.1 showing the average margins of victory in each national parliamentary constituency is simple: the larger they are, the less competitive is the electoral district. Because the quota-determined by population size-varies considerably across electoral districts, the average margin of victory in each district is then divided by the total number of valid votes cast in that constituency to produce the percentages in Fig. 7.1. To make it simple, I categorise the results into four broad groups. The first group is ultra-close conteststhose with a victory margin of less than one-half of $1 \%$. In 2014, the smallest margins were seen in West Java XI and East Java III-its precise margin 

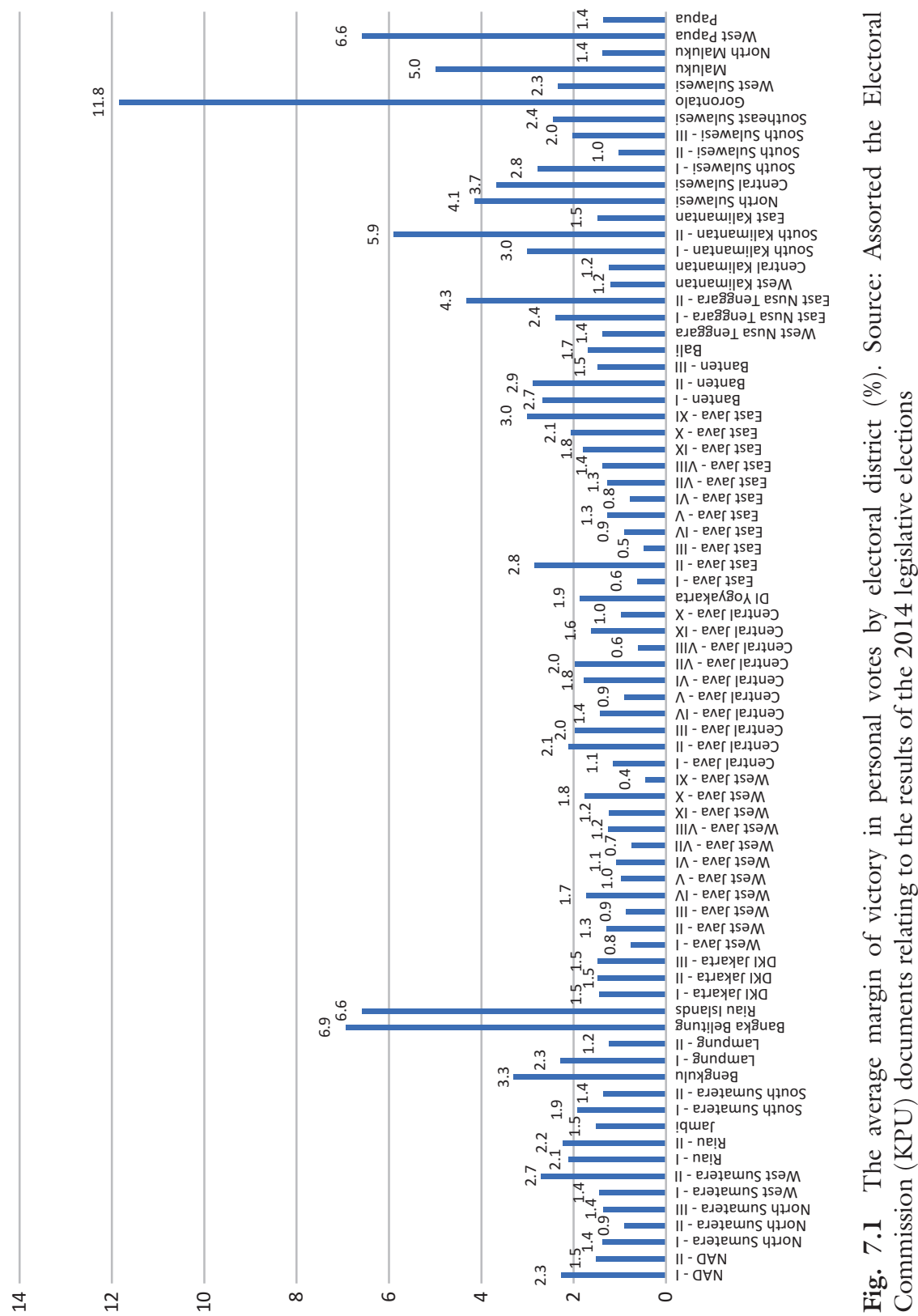
was actually $0.47 \%$, rounded up to $0.5 \%$ as appeared in Fig. 7.1 . The second is very close races, those with victory margins of between a half of $1 \%$ and $2 \%{ }^{6}$ The majority of constituencies ( 48 out of 77 electoral districts across Indonesia) belong to this group, confirming the hypothesis that the general pattern has been extremely competitive under open-list PR system. It is also worth noticing that in the above graph, most of those very close contests were located in the densely populated islands of Java and Sumatra with some of them decided by even less than $1 \%$ of the total polled votes.

The third group is close contests-decided by an average margin of between 2.1\% and 4\% in 2014. As shown in Fig. 7.1, 17 electoral districts are in this category. A last category is uncompetitive electoral districts which had an average winning margin of over $4 \%$. Interestingly, only a handful of constituencies were decided by big margins. The least competitive constituency in 2014 was Gorontalo, where winning candidates had an average $11.8 \%$ margin of victory, followed by Bangka Belitung which had a fairly high margin of $6.9 \%$ and Riau Islands and West Papua which equally had a margin of $6.6 \%$. These uncompetitive races all occurred in electoral districts with low magnitude with only three seats available in each constituency. This finding parallels Carey and Shugart's (1995: 431) argument that where district magnitude is higher, incentives to cultivate personal votes increase. Under open ballot systems, the higher a district magnitude, the more co-partisan competitors enter the race, resulting in more competitive elections as a result of increasing intraparty competition. The reverse is also true.

Overall, 69 out of 77 constituencies were decided by slim margins of less than $4 \%$, calculated as a proportion of all votes cast in the electoral district, suggesting that the level of competitiveness in the constituencies was extremely high. As noted above, such constituency-level campaigns were systematically associated with intraparty competition in which candidates from the same party were busy fighting against their co-partisans. Such fierce competition between individual candidates for personal votes helps explain why candidates pursue vote buying, despite its seemingly small effects on vote choice. Recall that the effect of vote buying on voting decisions was up to $10 \%$ of the electorate. There were around $187 \mathrm{mil}$ lion voters in Indonesia's 2014 legislative election. Even if we use such an estimate, the $10.2 \%$ effect would mean an estimated 19 million voters

${ }^{6}$ I adapt the first two categories from Ray Christensen and Kyle Colvin (2007). 
nationwide admitted that receiving money and gifts can be a crucial factor influencing their voting decisions.

Note that the estimates of vote-buying effectiveness are calculated as a percentage of those who received money from a candidate rather than the electorate. Given that 'only' 25\% of respondents were exposed to vote buying (based on the direct measure), and $41.8 \%$ of the recipients were influenced, in total numbers, vote buying had an influence on $10.2 \%$. The effect would likely have been higher if the candidates were able to distribute payments to more than a quarter of the electorate. Given that among those being targeted, $41.8 \%$ admitted that the handouts were effective at influencing their vote, it can be inferred the more the number of envelopes candidates distribute, the more likely they are to generate higher vote share. Let's say that an electoral district has $1,000,000$ valid votes, and an average margin of victory of $4 \%-4 \%$ is 40,000 votes. If a candidate gave cash to 100,000 voters, he/she would generate 41,800 votes $(41.8 \%$ of the 100,000 recipients), assuming he/she is the only candidate who engages in a vote-buying operation. This amount would be more than enough to explain the victory.

It is more complicated in practice, though. As I will explain in the next section, given that there are multiple candidates competing to purchase the votes, or even avidly bidding up the price of votes to defeat rivals (Aspinall et al., 2017), and the evidence that a significant number of the electorate received multiple payments, it would be difficult for candidates to assess how successful their vote-buying efforts was in generating votes. Therefore, many wealthy, serious candidates often double their efforts at vote buying in the hope of reducing uncertainty with regard to the election outcomes and maximising their individual chances of success.

This helps to solve the above puzzle of why politicians insist on spending money on vote buying in legislative elections, despite the fact that it is a strategy that would seem to fail to yield full effects. Despite vote buying being vulnerable to broker predation and the recipients not always repaying with votes, politicians believe that minor changes in voter supportwhether by buying votes or other electoral strategies - can make a difference to the outcome. ${ }^{7}$ Overall, this is in line with previous works (e.g. Jensen and Justesen, 2014), suggesting that vote buying is a key instrument for parties or candidates to create winning margins.

\footnotetext{
${ }^{7}$ For further discussion on the impact of competitive electoral settings where minor shifts in vote shares can change electoral results, see Milazzo and Karp (2013).
} 


\subsubsection{Intense Intraparty Competition}

Having established the average margin of victory in each constituency, we are now in a position to provide the average victory margin in each political party. As noted above, due to Indonesia's open-list PR system, which incentivises intraparty competition, this measure is a better indicator for assessing the competitiveness that candidates care most about. To arrive at the figure, the average margin of victory is calculated as the lowest winner's votes minus the losing runner-up's votes from the same party divided by the total number of valid votes polled for that party in the electoral district. Overall, the size of the winning candidate's victory within a political party varies significantly. For instance, the winning party in 2014, PDI$\mathrm{P}$, won 109 of the 560 seats in the national legislature, with the victory margins of these candidates over their nearest-placed PDI-P competitors ranging from $0.1 \%$ to $67.2 \%$. At the high end, PDI-P's Jimmy Demianus Ijie of West Papua defeated his nearest co-partisan by the widest margin. At the low end, PDI-P's Wiryanti Sukamdani of Jakarta I seat scraped through with a small margin of 441 votes or equal to $0.1 \%$, the lowest margin among all PDI-P winning candidates. A President Director and CEO of PT Sahid International Hotel, and a daughter of one of the richest men in Indonesia, Wiryanti not only defeated her nearest party rival Abadi Hutagalung, she also successfully unseated the incumbent candidate Adang Ruchiatna. As alluded to above, PDI-P candidates also fought in a close race to compete for the third seat in one of the party strongholds in Central Java V. The promising young professional Darmawan Prasodjo lost to Rahmad Handoyo by a margin of 485 votes or $0.1 \%$. Among electoral districts won by PDI-P, 27 constituencies witnessed victory with a margin of less than 4\%. Among others, East Nusa Tenggara I saw the closest fight as Honing Sanny, who polled 49,287 votes, beat an intellectualturned-politician widely known as Megawati's surrogate Andreas Pareira, who received 49,089 votes; West Java VII was among the most closely contested constituencies where four PDI-P candidates had a close fight to compete an additional seat received by the party.

Similarly, politicians from Golkar, the second-placed party in the 2014 legislative election, were forced to compete in very tight races against copartisan rivals in many electoral districts across Indonesia. Of the 91 seats the party won, 26 seats were close victories in which the winning candidates needed a margin of less than $4 \%$ to topple their internal competitor. In West Java XI, four candidates from Golkar initially had a chance of 
winning an additional seat. Ultimately, Zacky Siradj took home the prize by the lowest margin of $0.2 \%$. Likewise, in Central Java IV, Endang Maria Astuti, who occupied a low rank on the party list unexpectedly defeatedwith a victory margin of $0.3 \%$ - high-profile names from her own party, including the sitting candidate Hajriyanto Thohari, former Deputy Chairman of the People's Consultative Assembly (MPR), who ended in the third position. Golkar politicians from the outer islands also witnessed tight wins, including Indro Hananto who defeated his nearest party rival by a $0.3 \%$ victory margin in South Kalimantan I, Syamsul Bachri who won with a $0.6 \%$ margin in South Sulawesi II, and M. Lutfi who retained his constituency in West Nusa Tenggara, defeating his nearest rival by a margin of $0.9 \%$.

The third-placed party in 2014, Gerindra, also experienced highintensity campaigns among its candidates. Fourteen out of the 73 seats Prabowo's party won were decided by a margin of less than $4 \%$, with some won with a margin of less than $1 \%$. The striking example was Martin Hutabarat, who almost lost his seat in North Sumatra III to his party rival Sortaman Saragih. Only 27 votes separated the winning Martin from the losing candidate, meaning that the margin was basically zero. This was the lowest victory margin not only in that electoral district but also among all Gerindra winning candidates. Likewise, Gerindra's Dairul suffered defeat at the hands of his internal party competitor, H. Anda in Banten I constituency with a small margin of 332 votes. In West Kalimantan, Katherine Oendoen defeated her party rivals by a slim margin of $0.3 \%$, including Deputy Party Leader Arief Poyuono.

In a similar vein, a high degree of intraparty competition happened among the Democratic Party's candidates in 2014. A series of high-profile corruption scandals implicating its party executives (Aspinall et al., 2015a) forced its candidates not to rely on party branding but instead on their individual efforts, intensifying intraparty competition. Almost half of the 61 seats the party won in 2014 were decided by a margin of less than $5 \%$. Dramatically, among these lowest-margin wins, two seats saw victory with winner-loser differences of almost $0 \%$. Salim Mengga retained his constituency in West Sulawesi with a small margin of 25 votes after defeating the closest rival, Sulfia Suhardi. This was the lowest winning margin across national DPR constituencies in Indonesia and across the winning candidates in all political parties. Similarly, Ikhsan Modjo, an economist-turned politician and party leader's ally, was surprisingly defeated by a notorious local politician Ayub Khan with a margin of 57 votes in East Java IV. 
Smaller parties also deserve to be mentioned. In Papua, the internal political race within NasDem was heated as several high-profile candidates clashed with each other. Three candidates had a chance of winning, but Sulaiman Hamzah ultimately won the seat, defeating former two-term governor of Papua, Barnabas Suebu, with a small margin of $1 \%$. In general, at least a quarter of NasDem's victories in 2014 were closely contested within the party list. A high degree of uncertainty and intense intraparty competitions can produce what Christensen and Colvin (2007) termed 'election-night corruption' in which one candidate ends up engineering sufficient votes to defeat the nearest rival by a slim margin. For instance, Hanura's top-ranked politician Erik Wardhana was first announced to hold a narrow lead over his co-partisan rival Djoni Rolindrawan in West Java III. The initial vote tallies showed that the sitting candidate Erik would retain his constituency by a margin of $0.9 \%$. Djoni refused to concede, however, and reported Erik to the Elections Supervisory Agency (BAWASLU) and The Election Organisation Ethics Council (DKPP) for allegedly manufacturing votes to win the election. Having proved such fraud, both bodies recommended the General Election Commission (KPU) revise the vote tallies, and Djoni was then declared the winner (see DKPP's Putusan No 30 Tahun 2014; Media Indonesia, 22 September 2015).

Zero-sum intraparty campaigns also appeared among candidates running with Islamic political parties. Among the victories with the smallest margins in PKS, for instance, three seats had a margin of less than $1 \%$. Of the three, West Java V witnessed the closest fight as PKS' Soemandjaja won by a margin of $0.5 \%$ against his nearest party rival; Central Java III's Gamari and DKI Jakarta III's Adang Daradjatun were two of the candidates with $0.7 \%$ and $0.8 \%$ victory margins, respectively. Though not so tight compared to other political parties, intense campaigning among PPP candidates occurred in some electoral districts. Among others, Anas Thahir and Zaini Rahman were neck and neck in East Java III, with the latter trailing by just a $0.4 \%$ margin. The level of competitiveness among PKB's candidates seems to be higher than PPP. Around 11 of 43 seats received by this moderate Islamic party had a margin of between $0.1 \%$ and $3.4 \%$ compared to PPP that had less hotly contested battleground constituencies. Among others, PKB's Siti Masrifah won Banten III constituency, defeating her party rivals, including a well-known actor Tommy Kurniawan. The same is also true for candidates running with the Islam 
modernist party PAN. Almost one-quarter of its total 47 seats in 2014 were decided by a margin of less than $7 \%$.

Overall, the average difference between the vote share of the lowest winner and the losing runner-up's votes from the same party in a given electoral district was 31,801 votes. Table 7.3 shows that the absolute number of votes in the margin of victory in each political party varied slightly from 22,125 votes (Democratic Party) to 39,263 (PAN). In general, these absolute margins of victory in each party are relatively small if we divide by the total number of valid votes cast for all political parties in all electoral districts ( 77 constituencies). Column 3 of Table 7.3 shows that the average number of valid votes polled in each district was $1,584,463.9$ votes.

The results are largely self-explanatory: all political parties suffer from a high degree of competitive intraparty contests measured by a small margin of between $1.40 \%$ and $2.48 \%$. The pattern of intraparty competition among Democrats' candidates was highest, perhaps due to the decreasing popularity of the party, which forced its candidates to rely on their personal reputations, as discussed earlier. Meanwhile, though still competitive by any standard, candidates running with PAN witnessed victory with the highest margin compared to other parties. Overall, however, candidatelevel competition in seeking personal votes in Indonesia is comparatively high since it only needs a margin of $1.65 \%$ of votes cast for that party on

Table 7.3 Average margins of victory by political party

\begin{tabular}{lccc}
\hline $\begin{array}{l}\text { Political } \\
\text { parties }\end{array}$ & $\begin{array}{c}\text { Average margin of victory } \\
\text { in each political party }\end{array}$ & $\begin{array}{c}\text { Average number of valid } \\
\text { votes per electoral district }\end{array}$ & Percentage \\
\hline NasDem & $35,516.7$ & $1,584,462.9$ & 2.24 \\
PKB & $30,180.2$ & $1,584,462.9$ & 1.90 \\
PKS & $28,500.4$ & $1,584,462.9$ & 1.80 \\
PDI-P & $23,080.2$ & $1,584,462.9$ & 1.46 \\
Golkar & $23,387.1$ & $1,584,462.9$ & 1.48 \\
Gerindra & $25,530.5$ & $1,584,462.9$ & 1.61 \\
Democratic & $22,124.9$ & $1,584,462.9$ & 1.40 \\
Party & $39,263.1$ & & \\
PAN & $35,049.7$ & $1,584,462.9$ & 2.48 \\
PPP & $23,247.6$ & $1,584,462.9$ & 2.21 \\
Hanura & & $1,584,462.9$ & 1.47 \\
\hline
\end{tabular}

Source: Assorted the Electoral Commission (KPU) documents relating to the results of the 2014 legislative elections 
average for a candidate to win the final seat won on their party list. This finding is compatible with previous works (e.g. Christensen and Colvin, 2007), suggesting that the level of between-candidate competition in multi-seat districts is likely to be more competitive since the vote share of the lowest winner and the losing runner-up will be much closer to each other compared to elections in single-seat districts. ${ }^{8}$

\subsubsection{Electoral Competitiveness and Vote Buying}

Having discussed the zero-sum nature of intraparty competition, we now turn to examine the relationship between variations in electoral competitiveness and vote buying. Accordingly, I need reliable data on the level of vote-buying incidents at the electoral district level. Pre-election surveys conducted by my polling organisation Indikator before the national legislative election in 2014 are a good source of data for that purpose. In these surveys, multistage random sampling was used to produce a sample that enables us to make inferences and generalisations about the target population. I use 13 surveys with a total number of respondents of 9344 , with the numbers per electoral district varying considerably from 410 to 2387 respondents.

Table 7.4 illustrates vote-buying incidence and the average margin of victory in 13 electoral districts. ${ }^{9}$ The wording used to measure vote buying in these surveys was: "During the run-up to the April 9th 2014 election, did you observe candidates or success team members offering you money, food, household items, and/or other goods (excluding propaganda hats, shirts, and posters)?" Unfortunately, the district surveys were conducted about two months prior to the elections, while vote buying typically takes place or accelerates during the last few days leading up to the polls. We can therefore assume that such practices aren't fully captured by these surveys.

\footnotetext{
${ }^{8}$ Again, regarding the electoral effect of vote buying that stood at $10.2 \%$ of the electorate, what candidates care most about is how to win the election by a margin that fell within $10.2 \%$ of their own personal vote. Recall that it isn't the total party vote that really counts, but the number of voters a candidate distributed money to.

${ }^{9}$ My polling institute Indikator, along with SMRC, together actually conducted electoral district surveys in 73 out of 77 constituencies. Unfortunately, the wording used wasn't the most explicit version possible to uncover vote buying behaviour. The question was only intended to measure how acceptable vote buying was according to respondents, which of course doesn't allow us to measure whether voters actually accepted electoral bribes or even received vote buying offers.
} 
Table 7.4 Vote buying and winning margins in 13 electoral districts (\%)

\begin{tabular}{lcc}
\hline Electoral districts & Vote buying $(y)$ & Winning margin $(x)$ \\
\hline West Sumatra-II & 3.80 & 2.72 \\
West Java-VII & 12.77 & 0.75 \\
West Java-XI & 7.73 & 0.44 \\
Central Java-III & 5.20 & 1.98 \\
Central Java-V & 6.17 & 0.90 \\
Central Java-VI & 3.66 & 1.77 \\
Central Java-VIII & 6.48 & 0.61 \\
East Java-II & 6.93 & 2.84 \\
East Java-V & 5.36 & 1.26 \\
East Java-VIII & 7.14 & 1.38 \\
East Java-IX & 8.46 & 1.79 \\
East Java-XI & 4.60 & 3.01 \\
Southeast Sulawesi & 7.98 & 2.45 \\
\hline
\end{tabular}

But though the available data likely seriously underestimate levels of vote buying, they do allow comparison across a number of electoral districts and therefore help us examine whether a high degree of competition actually drives candidates to engage in vote buying. If this is true, it should be reflected not only in a few days before an election but also some months before the voting day.

To test the impact of electoral closeness on vote buying, I examine the relationship between individual-candidates-level competition and vote buying as a better measure for determining the level of competitiveness in settings like Indonesia where under open-list electoral system, every individual candidate fights for personal votes. Electoral competitiveness in each district should be put in the context of candidate competition within parties and between parties. This is to gauge the extent to which the level of intra- and interparty competition within districts shapes vote buying. Given each electoral district had multiple seats being contested, I include the average margin of all winning candidates across political parties.

In Fig. 7.2, each dot is one candidate gaining the final seat won by his/ her political party. In 2014, of the races for which I have relevant survey data available, there were 92 seats available in 13 electoral districts. At the top of centre point is NasDem's Hasan Aminuddin of East Java II, who won by a large margin in a district whose respondents reported receiving attempts at vote buying at a roughly average rate. At top right is West Java 


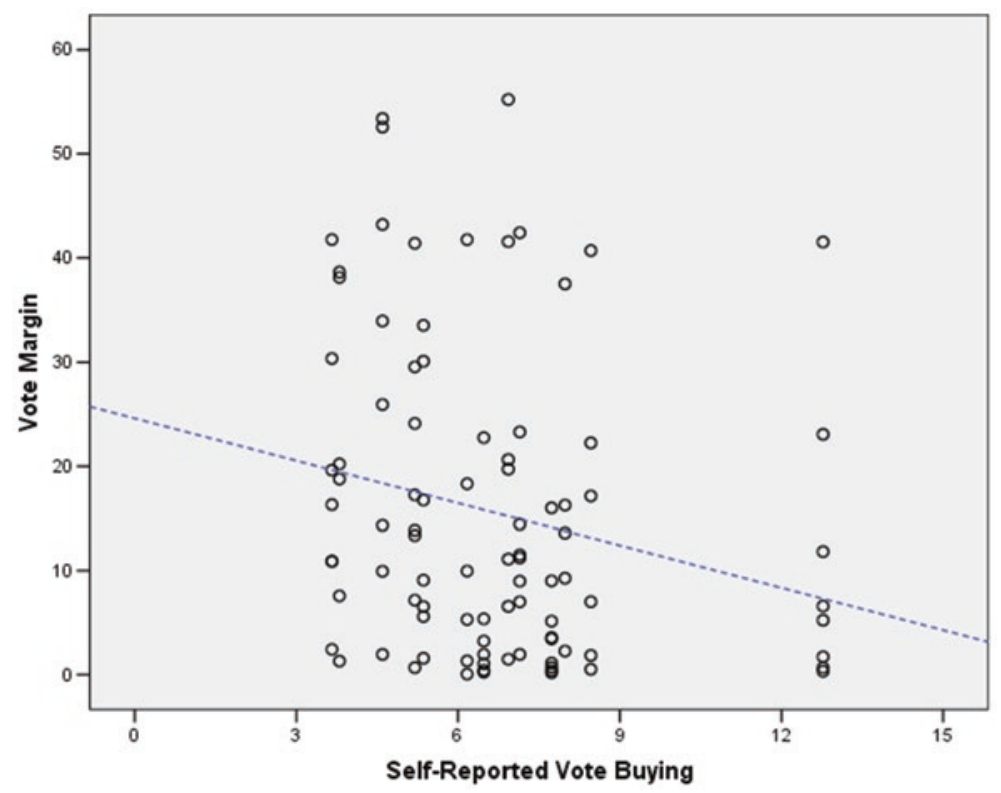

Fig. 7.2 Correlations (Pearson's $r$ ) between competitiveness and vote buying within electoral districts $(\%)$

\begin{tabular}{lccc}
\hline & \multicolumn{3}{c}{ Vote buying } \\
\cline { 2 - 4 } & $N$ & Correlation & Sign. \\
\hline Vote margin & 92 & $-0.218^{*}$ & 0.036 \\
\hline
\end{tabular}

VII, home of PPP's Wardatul Asriah who won by a fairly high margin in the constituency, where respondents reported the highest rate of vote buying. At bottom left is PPP's Muhammad Iqbal of West Sumatra II, who won by a slim margin in a district where its residents were less likely to be exposed to vote buying. 
The dashed line in Fig. 7.2 demonstrates the overall trend. The line falls to the right, again showing that the correlation is in the expected direction, implying that the relationship between competitiveness of elections - marked by smaller winning margins — and vote buying really exists. The Pearson's correlation test returned a significance level of 0.036 , proving that the two variables do have a statistically significant relationship. We can be reasonably sure that, as electoral contests grow more competitive, average levels of vote buying increase. It is worth noticing, though, notwithstanding a clear correlation between competitiveness and vote buying, there is a causal issue. This study is unable to assess whether more competitive electoral districts make candidates to buy votes or whether the opposite is true: more vote buying generates more competitive elections.

To sum up, regardless of such chicken and egg problem, the analysis confirms much of the existing literature that states electoral systems shape politicians' strategies and behaviour. When the election of candidates within party lists is dependent upon securing a personal vote, they will respond to such competition by building personal appeals rather than relying on party reputation (Chang, 2005; Carey and Shugart, 1995). Under these circumstances, what matters most in the open-list campaigns is intraparty competition rather than interparty competition. As I have argued, it is the competition between candidates within a party list that makes them engage in more intense personal campaigning (Selb and Lutz, 2015). Given that seats are taken by candidates who obtain the most votes from each list, intraparty competition under the open-list system increases candidates' electoral uncertainty. The dominant narrative among candidates is that they were all dubious about their chances of getting elected-not only rank-and-file candidates placed low on their party list but also party leaders who were placed high.

The link to vote buying is therefore doubly clear: first, when candidates are forced to compete against co-partisans, they can no longer rely on their party label to take them into parliament, and they have clear incentives to differentiate themselves in other ways (Aspinall and Sukmajati, 2016: 13); second, when elections become highly contested, and a relatively small proportion of the overall votes cast can make a difference, strategic investment in vote buying can be expected to alter the outcome of the election. Because the open ballot system only requires candidates to provide a small slice of the vote to beat their co-partisans, the value of each vote increases. Therefore, while vote buying gains a seemingly small percentage of the overall vote, this can be more than enough to help a 
candidate win in a narrow race. My finding clearly shows that vote buying is an integral part of highly competitive elections. Given the significance of vote buying in determining the final results, my finding slightly differs from previous work by Aspinall and his collaborators (2015b), which suggests that cash handouts in Indonesia are more about meeting an 'entryticket' expectation and less about actual vote choice or turnout. I would argue that it seems to play a deceptively small, but in fact very consequential role in determining electoral outcomes.

\subsection{Two Alternative Theories}

I have endeavoured to answer one of important puzzles underlying this book that revolves around the question of why candidates engage in vote buying while these monetary incentives appear to influence 'only' a limited number of people. As noted above, in closely contested elections such as those in Indonesia, even if vote buying is proven to produce very low returns (due to the problem of voter compliance and broker predation), such a strategy can make a real difference to election outcomes. This explanation, however, leaves a question unanswered: if it were, then we would expect candidates in very close races to spend much more on vote buying, and candidates who expect to win comfortably, to spend less. This leads me to propose two alternative explanations for why candidates might still prefer vote buying, even when the returns are so poor, and even if they aren't in a particularly close race: (1) candidates are trapped in prisoner's dilemma types of situation and (2) vote buying may be an objectively inefficient strategy for mobilising votes, but still be relatively more efficient than all the viable alternatives.

\subsubsection{The Prisoner's Dilemma}

As previously discussed in Chap. 4, as the election drew nearer, the magnitude of vote-buying efforts increased significantly. In January 2014, only $4.3 \%$ of voters were exposed to vote buying. As the election period was approaching, however, those who reported being targeted with benefits experienced a sixfold increase with about $25 \%$ of voters reporting such exchanges. Not only did the percentage of those being targeted by vote buying rise dramatically but also the incidence of multiple payments increased. Using extensive survey data, I found a consistent pattern in which, as the election drew nearer, it became more likely that a voter had 


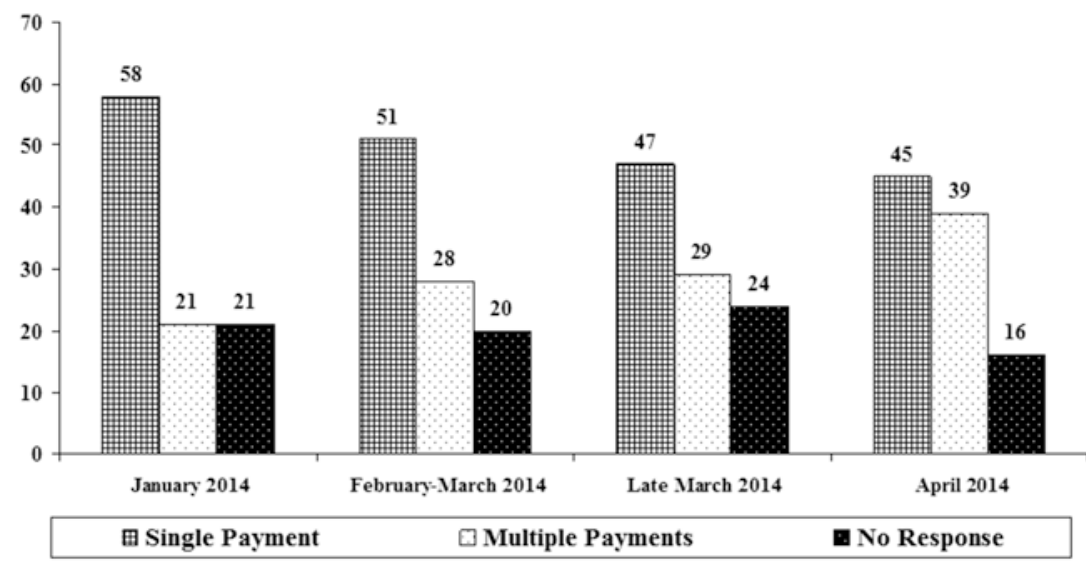

Fig. 7.3 How massive were multiple payments in Indonesia? (\% of those saying they had been targeted for vote buying). Source: The January, February-March, and late March 2014 data were taken from my pre-election surveys, while the April 2014 numbers were drawn from my post-election survey (see Appendix A)

received payments from more than one party. During the run-up to the legislative elections, I held monthly nationwide surveys asking the respondents, using exactly the same wording, whether they had been targeted for vote buying. A follow-up question asked those who responded affirmatively: "Which party or candidate or success team from which party offered you those goods/gifts?" (Fig. 7.3)

Given that respondents were allowed to give multiple answers, I then recoded the responses to this question to show vote buying by multiple parties. Recall that due to the nature of question and options provided, this exercise can only capture interparty duplication of vote buying efforts, not whether multiple candidates within the same party were providing payments, which was also quite possible due to the open-list PR system. Apparently, candidates believed that a final push could make the difference between winning and losing (candidate from PDI-P, informal communication, 20 April 2014).

The proximity of the election boosts vote-buying incidence largely because of a popular belief among candidates that voters will often vote for the candidate who gave the payment the last and because that candidate will be fresh in the memory. The prisoner's dilemma offers a potential 
answer for the breadth of this last-minute panic. Candidates might stand to gain more financially if all of them didn't engage in vote buying. But the risk of being trumped for an individual who doesn't participate when others do so, means that such people might feel they have little choice. Applying the prisoner's dilemma to candidates' behaviours when the elections draw near, a candidate will be keen to pursue vote buying if other candidates are using the same strategy. They often see distributing gifts as their best chance of stopping other candidates from winning votes (Guardado and Wantchekon, 2014). For example, a successful candidate from Indonesia's biggest Islamic party admitted to pouring money into the electorate on voting day up until $9 \mathrm{am}$, having seen an opponent distributing cash just before the polling stations were opened. He defended his actions:

It isn't only a 'dawn attack' [a universally recognised term that reflects the fact that payments are sometimes distributed just after the dawn prayer]. It is also a 'serangan duha' (dhuba attack) [referring to Dhuba or mid-morning prayer time, which is performed immediately after sunrise when the sun has risen to a certain height]. (Interview, 20 April 2014)

The prisoner's dilemma can be best explained in a context of high competitiveness where uncertainty is great regarding the electoral outcome. Under open ballot systems dominated by personal votes, the personal incentive to win is high, leading candidates to use all available means in their campaigns, including making payments to voters, especially if they see multiple candidates doing it. In the prisoner's dilemma, Takeuchi (2013: 78) points out, “each player's rational strategy to maximise his or her individual payoff ends up with a worse outcome than some other possible outcome that may be better for both players." In the face of closely contested races, the probability of each candidate engaging in vote buying increases, given that small changes in support can be expected to alter the outcome of the election.

In the context of such competitive elections, candidates' strategies are often determined by their competitors' actions. They claim that participating in buying votes, including providing multiple payments to voters, is the best way to tie voters so they didn't turn to cashed-up rivals. As discussed in Chap. 4, candidates and brokers who do this are trying to 'secure' their vote from 'dawn attacks' carried out by other teams. The results from my broker survey confirmed that, when asked to observe 
other success teams, $28 \%$ of the respondents claimed a significant number of other teams delivered cash more than once. As discussed in Chap. 4, many surveyed brokers used the verbs 'to tie' (mengikat) or 'to secure' (mengamankan) when describing the function of the second payments, which is consistent with my qualitative and in-depth interviews with highlevel politicians. Brokers often told candidates to make follow-up cash payments in response to late manoeuvres by rivals. The sense of lastminute panic is evident where the majority of brokers heard that during the cash envelope distribution phase, other success teams were doing the same thing in the same village, but with larger sums of money (see Fig. 7.4). This exactly mirrors the prisoner's dilemma, as discussed above.

Candidates might end up playing the prisoner's dilemma against each other not only because of the presence multiple gift givers but also as a response of voters' expectations of monetary rewards. Such voters were accused of being merely driven by money and choosing to vote for rival candidates who paid more. Indeed, there is some anecdotal evidence that voters simply auction their votes off to the highest bidder. One excellent study by Aspinall and Sukmajati (2016) asserts that voters were increasingly ruled by a pragmatic and transactional logic and political actors tried to meet such expectations. Ahmad Muzani of Gerindra told me that a vast majority of voters in his electoral constituency in Lampung I were basically

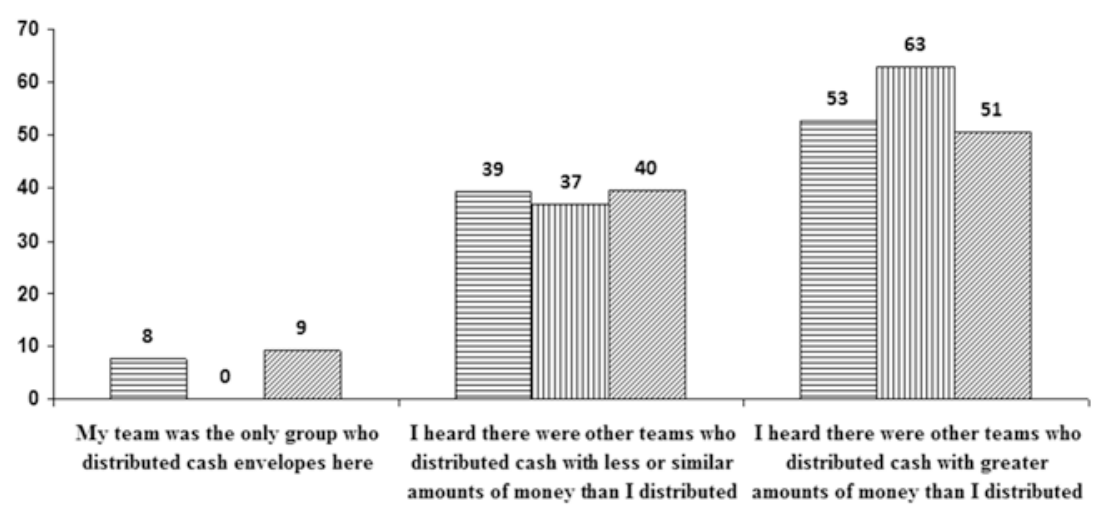

目 All sample

U Provincial DPRD brokers Q District DPRD brokers

Fig. 7.4 Other teams also distribute cash envelopes (\%). Source: My survey of brokers, 30 September-25 October 2014 
materialistic voters, and that there were numerous reports of locals receiving five to eight envelopes from several brokers. "What can I say? It's the time for them to harvest money (panen uang) during election season" (Interview, 13 April 2014). Tubagus Ace Hasan of Golkar reported another colourful story. In his constituency in Banten I, a night before the voting day, the consumption of catfish increased because locals usually hold dinner parties with catfish recipes while waiting for cash envelopes from brokers (Interview, 14 April 2014).

While acknowledging vote buying is a highly uncertain business, and its effectiveness in driving votes is relatively weak, candidates felt insecure about their electoral prospects if they didn't bid on such purely materialistic voters in the midst of rampant handout distribution by other rival candidates. Despite its feeble effectiveness in ensuring victory based on empirical data analysis outlined above, not engaging vote-buying strategies are too great a risk to contemplate as it is widely assumed to be a path to electoral collapse. In this regard, the rationale behind such strategies aren't to 'buy' votes per se, but instead it is widely employed as a countermeasure to neutralise or minimise the electoral gains by their rivals in the context of a highly competitive zero-sum electoral competition. That's why candidates insist on pursuing vote buying, despite such strategy having not always produced the vote that was hoped for, and despite its vulnerability to the problem of broker predation and voter compliance.

\subsubsection{Relatively Move Efficient Strategy}

The second plausible interpretation on why candidates still choose to buy votes is that this electoral strategy may be fairly inefficient, yielding low returns on investment, although it is still relatively more efficient than all the other feasible alternatives. The fact that Indonesia's candidate-centred election system provides strong incentives for using personal campaigns doesn't automatically imply that money politics will be the only or favoured tactic for pursuing those strategies (Hicken, 2007: 53). In an attempt to win office, candidates might use a variety of means and methods to generate personal votes, including club goods,${ }^{10}$ vote coercion, or using media advertising to increase individual popularity. Another personal strategy includes those candidates who have access to state resources in targeting their constituencies. Note that these strategies can interact or occur together at some point in time when implemented in the field (Hicken,

\footnotetext{
${ }^{10}$ Aspinall and Sukmajati (2016: 23) define club goods as "patronage that is provided for the collective benefit of bounded social groups rather than for individuals."
} 
2007). In Indonesia, for instance, club good provision tends to be combined with other forms of patronage politics, especially vote buying.

I argue that compared with all the viable alternatives, vote buying still emerges as being relatively efficient in driving votes, despite weak monitoring and limited direct yields. Much of the literature on club goods in Indonesia, for instance, shows that such collective patronage, typically consisting of small-scale infrastructure projects or donations to certain associations, is a less reliable strategy in winning votes (Aspinall and Sukmajati, 2016: 23). This corresponds with the popular narrative among candidates that spending money on club goods is a wasteful strategy since they have no guarantees that neighbourhood or community associations that received the benefits will repay the favours with their vote. The provision of club goods is prone to the individual behaviour and perception risk akin to general phenomenon found in the utilisation of common goods called 'tragedy of the commons.' This is basically a situation in a shared resource distributive system where individual voters who receive some benefits as a member of a collective have a perverse tendency to perceptively view the club goods as common collective goods, hence their individual votes tend to be directed elsewhere as they wish or even allowing them not to vote at all since the burden of voting has been shifted to the common or collective efforts. A candidate from PAN, also shared this view, arguing that the provision of club goods was wasteful, in part, because it was ineffective in swaying voters' choices. In his own words:

Many incumbent candidates, long before the elections, had in fact distributed a lot of social assistance to voters, renovated mosques, paid for road repairs, and so on and so forth. But, ironically, they lost to candidates who launched 'dawn attacks' by simply distributing small payments to voters just before the election. Caring for the needs of community is of course important, but it wouldn't be enough. They (the voters) expect to receive concrete, immediate payments. (Interview, 22 April 2014)

Similarly, voter intimidation isn't also a preferred strategy for most candidates in Indonesia because it is simply too risky and costly. That is why, in 2014 election, only a very few people experienced any intimidation from a particular candidate's supporters or campaign team members. My post-election survey of voters found that only $1.7 \%$ of respondents admitted being a victim of such coercion. From the perspective of candidates, voter intimidation faces restrictive constraints in terms of money, human resources, and networks (Hicken, 2007). This strategy also has 
sketchy records in ensuring comfortable victory margin in an electoral contest. Moreover, the use of threat of violence generally carries greater risks compared to relatively safer vote-buying strategy. As already explained in Chap. 2, vote buying has become a common feature in Indonesia's electoral politics, partly due to the problem of law enforcement mechanisms to proceed with such electoral fraud.

Candidates may prefer vote buying instead of or in addition to the use of mass media or social media in supporting individual campaigns. As previously discussed, in the context of candidate-centred elections, the individual popularity is a key determinant electoral success for candidates. Therefore, candidates are expected to use the media campaign to reach out to a vast majority of voters, without completely ignoring the importance of conventional means of campaigning such as direct contact with voters, outdoor campaigns, and other personal strategies such as vote buying. Utilising from a large dataset of voters' surveys in 73 out of 77 electoral districts across Indonesia, I find that the use of mass media in supporting individual campaigns was apparent, but the scale was much less than many observers have expected (i.e. Ufen, 2006), as I will demonstrate in the following pages.

In order to provide a sense of comparison between various methods used especially by incumbent candidates to win personal votes, and to explain the significance of vote buying for candidates to win the seat, I first conduct cross-sectional analysis, that is, comparison among incumbent candidates according to their electoral outcomes (i.e. between the successful and losing incumbent types). In doing so, we are allowed to assess what sort of personal appeals did candidates choose to make in 2014 and voters had most often seen in their neighbourhood? My next strategy is to make a comparison of victorious versus losing incumbents based on individuals' responses towards a variety of means and methods employed by candidates. In my massive surveys in 73 out of 77 electoral districts across Indonesia during the run-up to the 2014 legislative elections, respondents were asked to name which of the following candidates in their respective electoral districts they had most often seen in direct campaign, seen on TV, read in the newspapers, heard on the radio, seen or read on the Internet/twitter/SMS/Facebook called social media campaign, or seen on the banners or posters called outdoor campaign. ${ }^{11}$ In addition,

\footnotetext{
${ }^{11}$ This can be done only for incumbent candidates who possess all variables being tested. Accordingly, there were 339 incumbent candidates who can be analysed for purpose of this study, accounting for about $68 \%$ of 502 incumbents seeking for another term in office in 2014. Admittedly, this study lacks representation from the incumbents competing in Eastern part of Indonesia.
} 
these massive surveys measure vote-buying acceptability by asking the respondents: "As an effort to win the legislative election, certain candidates or campaign team members gave money or gifts for people to influence their votes. In your opinion, does the money/gift can be considered as something acceptable or unacceptable?" While the wording doesn't allow us to measure whether incumbents actually distributed cash handouts and voters subsequently accepted, it does allow us to measure how prevalent voters' expectation of vote buying is in one's electoral district.

Table 7.5 displays mean scores of individuals' responses about what sort of personal strategies that winning and losing incumbents made and had been most observed by voters. In general, successful incumbents evidently reached out to more voters through various strategies than the losers. Their campaign materials had greater visibility (i.e. through direct contact, mass media, and social media exposure) than that of the losers, suggesting that they were clearly losing the ground-war campaign. All of this suggests that relative to the victorious incumbents, the losers were evidently having difficulties in reaching voters, a fact which may help explain why they were unsuccessful. Overall, the use of media advertising to cultivate personal appeals wasn't a popular strategy for candidates. The pattern prevails, however, in which the victorious incumbents were likely to gain more exposure than the losers. They even gained more exposure in social media, although the Internet use was still limited in Indonesia.

Overall, however, my study found that most incumbent candidates still resort primarily to the traditional means of campaigning such as direct and outdoor campaigning (i.e. publicly visible posters and banners). Table 7.5

Table 7.5 Descriptive statistics (mean scores) of a variety of methods employed by winning and losing incumbent candidates in 2014 (\%)

\begin{tabular}{|c|c|c|c|c|c|c|c|}
\hline $\begin{array}{l}\text { Electoral } \\
\text { outcomes }\end{array}$ & $\begin{array}{c}\text { Direct } \\
\text { exposure }\end{array}$ & $\begin{array}{c}T V \\
\text { exposure }\end{array}$ & $\begin{array}{c}\text { Newspaper } \\
\text { exposure }\end{array}$ & $\begin{array}{c}\text { Radio } \\
\text { exposure }\end{array}$ & $\begin{array}{l}\text { Social } \\
\text { media }\end{array}$ & $\begin{array}{l}\text { Outdoor } \\
\text { campaign }\end{array}$ & $\begin{array}{c}\text { Vote } \\
\text { buying }\end{array}$ \\
\hline \multicolumn{8}{|c|}{ Successful } \\
\hline Mean & 2.15 & 3.93 & 2.14 & 1.09 & 0.78 & 9.69 & 46.93 \\
\hline$N$ & 219 & 158 & 160 & 141 & 198 & 221 & 182 \\
\hline Std. & 2.29 & 6.52 & 2.89 & 1.6 & 1 & 8.5 & 11.93 \\
\hline Deviation & & & & & & & \\
\hline \multicolumn{8}{|c|}{ Losing } \\
\hline Mean & 1 & 1.91 & 1.41 & 0.6 & 0.48 & 5.46 & 43.87 \\
\hline$N$ & 208 & 158 & 148 & 131 & 176 & 222 & 200 \\
\hline Std. & 1.07 & 3.71 & 1.87 & 0.63 & 0.59 & 5.62 & 10.25 \\
\hline Deviation & & & & & & & \\
\hline
\end{tabular}


demonstrates that people were more likely to be exposed by outdoor campaigns than other means of campaigning. There were two reasons behind the incumbents' preference to traditional methods of campaigning than the use of media campaigns. First, this study found that the regular access to the print media, radio, and social media is still limited in most electoral districts in Indonesia. Out of the already limited readership figures for newspapers and small numbers of people who tuned in to the radio broadcast, adding to it those who have Internet access, most of them were not drawn into political news in the first place. This study suggests that investing large sums of money in expensive media campaigns may be wasteful for incumbents. Second, placing advertisements in television is still more beneficial as it has extensive coverage area of up to $90 \%$ of the population in Indonesia, although the cost is very expensive. Moreover, television exposure isn't suitable for candidates running in a particular electoral district because they don't need to penetrate wider audiences. Therefore, it is an unsurprising fact when the majority of candidates don't rely on the media as a major means of campaigning, but instead relying simply on placing campaign banners and posters as well as face-to-face meetings.

Interestingly, we see a marked difference too in mean scores of individuals who professed that vote buying is acceptable between the winning and losing incumbents' constituencies. The winning incumbents were more likely to run in areas where voters are actually more accepting of vote buying than the losers. The finding provides suggestive evidence that successful incumbents were found to run disproportionately in places where voters perceive vote buying as a normal occurrence during elections. The analysis of variance (ANOVA) analysis further confirms the finding that successful and unsuccessful incumbents generally have significant different characteristics in terms of the level of vote-buying acceptability in their respective districts. Using a logistic regression model (see Appendix F), vote buying-defined as incumbents' electoral districts whose voters have no problems accepting cash or a gift-stands out as a key determinant of electoral success for their re-election bid. Its substantive effect reaches statistical significance at the 95\% level, and it is independent from the influence of other factors included in the equation (i.e. gender, position on party list, name recognition, running in the same electoral district, and district magnitude). A one-unit increase in the level of vote-buying acceptability in the incumbents' districts resulted in an increase of about 2-3 percentage estimate point in the likelihood of being re-elected.

The results from these massive electoral district surveys of voters are consistent with the candidate narrative. In my winning candidate survey, almost $70 \%$ of respondents opined that the voters in their constituencies were increasingly pragmatic at election time, expecting monetary incen- 
tives in return for their votes. As argued by Hicken (2007), such cultural norms of gift giving not only create a social atmosphere conducive to vote buying but also make this strategy a more appealing avenue for candidates relative to other personal strategies. Although there is accumulating evidence that electoral handouts are oftentimes not quite an effective strategy due to the mistargeting story and brokers' rent-seeking behaviour (see Chap. 5), but nevertheless, relative to other personal strategies, vote buying remains to be the more effective one in securing votes and actually help politicians win.

\subsection{Conclusion}

This chapter has endeavoured to show the effect of vote buying on voting behaviour in Indonesia. It began with the puzzle about misdirected targeting of vote buying and brokers' rent extraction that might undermine its impact on vote choice. If such a strategy is largely ineffective, why would candidates invest scarce resources in it? But, if vote buying is truly effective, how big or small is the effect and what does it mean and for whom? I have shown in this chapter that vote buying is indeed effective in producing both greater turnout and greater vote share, but the effect is limited to a small minority of voters. In terms of the effect of vote buying on turnout, I have shown that exposure to clientelism has a positive effect on the likelihood of turning out to vote. Rates of electoral participation are significantly higher among those who received cash handouts than those among who didn't ( $81 \%$ vs. $74 \%$ ).

Regarding the effect of vote buying on voting choice, I have demonstrated that the estimated effect of such practice lies at $10.2 \%$. Note that the $10.2 \%$ effect of vote buying is estimated based on those who experienced vote buying compared by the total electorate. If we specifically focus on the effect of vote buying among those who received payments from candidates $(25 \%$ based on a direct survey item), its impact on vote choice was up to $41.8 \%$ of the recipients. Hence, in fact, the percentage of the total number of those whose votes can be bought must have been higher if machines are capable of handing out money to voters to more than a quarter of the whole electorate. But, in total numbers, the electoral effect of vote buying in legislative elections was 'only' $10.2 \%$ of the whole electorate.

My results answer a critically important question: if it is true that vote buying has a relatively trivial effect-in the sense that it only affects the voter choice of about $10.2 \%$ of voters-why do politicians insist on pursu- 
ing such a strategy? I showed in Chap. 2 that vote buying has become an increasingly prominent electoral strategy. But judging the effect of such vote buying without contextualising it within the context of the electoral system where candidates compete and interact can be difficult. What we really want to know isn't 'how significant is the effect of vote buying,' but 'is it significant enough to achieve a desired outcome?'

Therefore, I have demonstrated at length in this chapter that the seemingly trivial effect of vote buying on voting choice in fact is quite large enough to frequently determine the outcome of electoral races in Indonesia. In an environment where elections are shaped by intraparty competition like Indonesia, candidates depend on personal votes to defeat co-partisans. Under such circumstances, electoral uncertainty regarding the electoral outcomes increases. To measure this, I use victory margins to assess how competitive parliamentary elections in 2014 were in each political party. The empirical evidence reviewed in this chapter reveals that the average margin of victory within political parties - by which winning candidates defeated their internal party rivals-was only $1.65 \%$. Here lies the key to why vote buying remains an attractive investment and has been widely practised in Indonesia. While the effect of vote buying on voter turnout and vote choice may appear small, in Indonesia's highly competitive election settings, that $10.2 \%$ matters significantly. The marginal value of each voter collected through buying votes is high enough to constitute narrow winning margins, which helps explain why candidates pursue vote buying, despite its seemingly small effects on voting behaviour.

However, the margin argument raises a further question: why there are still many competitive polities where the vote margins are small, candidates don't engage in vote buying? I have argued that candidates might still prefer vote buying, even when such practice is proven to produce low returns, in the midst of massive money politics distributed by other rival candidates. In a context where multiple candidates were engaged in vote buying, anxious candidates poured money into handout-responsive voters. As such, candidates' decisions to intensify vote-buying efforts were often like last-minute panic buying. What matters isn't whether candidates actually buy a vote, rather that vote buying is a counter-instrument to neutralise their opponents' strategies. In addition to being trapped in a prisoner's dilemma, candidates insist to buy votes because this strategyalthough proved ineffective in yielding significant votes-but, nevertheless, relative to other personal strategies, vote buying still produces votes that may be more than enough to secure a victory. 


\section{BIBLIOGRAPHY}

Books, Journal Articles, and Unpublished Papers

Aspinall, E. and Sukmajati, M. (eds) (2016) Electoral Dynamics in Indonesia: Money Politics, Patronage and Clientelism at the Grassroots. Singapore: NUS Press.

Aspinall, E., Mietzner, M., and Tomsa, D. (2015a) The Yudhoyono Presidency: Indonesia's Decade of Stability and Stagnation. Singapore: ISEAS.

Aspinall, E., Davidson, M., Hicken, A., and Weiss, M. (2015b) Inducement or Entry Ticket? Broker Networks and Vote Buying in Indonesia. Paper presented at American Political Science Association Conference, 3-6 September, San Francisco.

Aspinall, E., Rohman, N., Hamdi, A.Z., Rubaidi, and Triantini, Z. (2017) Vote Buying in Indonesia: Candidate Strategies, Market Logic and Effectiveness. Journal of East Asian Studies 17: 1-27.

Baldwin, K. (2016) The Paradox of Traditional Chiefs in Democratic Africa. Cambridge: Cambridge University Press.

Blais, A. and Lago, I. (2009) A General Measure of District Competitiveness. Electoral Studies 28: 94-100.

Brusco, V., Nazareno, M., and Stokes, S. (2004) Vote Buying in Argentina. Latin American Research Review 39(2): 66-88.

Carey, J. and Shugart, M.S. (1995) Incentives to Cultivate a Personal Vote: A Rank Ordering of Electoral Formulas. Electoral Studies 14(4): 417-435.

Chang, E.C.C. (2005) Electoral Incentives for Political Corruption under Openlist Proportional Representation. Journal of Politics 67(3): 716-730.

Christensen, R. and Colvin, K. (2007) Stealing Elections: A Comparison of Election Night Corruption in Japan, Canada, and the United States. Paper presented at the Stanford Conference on Electoral and Legislative Politics in Japan, 11-12 June.

Finan, F. and Schechter, L. (2012) Vote Buying and Reciprocity. Econometrica 80(2): 863-881.

Franklin, M.N. (2004) Voter Turnout and the Dynamics of Electoral Competition in Established Democracies since 1945. Cambridge: Cambridge University Press.

Guardado, J. and Wantchekon, L. (2014) Do Electoral Handouts Affect Voting Behavior? Working Paper No. 171, Afrobarometer.

Hicken, A. (2007) How Do Rules and Institutions Encourage Vote Buying? In: F.C. Schaffer (ed) Elections for Sale: The Causes and Consequences of Vote Buying. Colorado: Lynne Rienner Publisher, Inc.

Ibrahim. (2016) Bangka Belitung: Patronage and Identity Politics in a Plural Society. In: E. Aspinall and M. Sukmajati (eds) Electoral Dynamics in Indonesia: 
Money Politics, Patronage and Clientelism at the Grassroots. Singapore: NUS Press.

Jensen, P.S. and Justesen, M.K. (2014) Poverty and Vote Buying: Survey-based Evidence from Africa. Electoral Studies 33: 220-232.

Kitschelt, H. and Wilkinson, S. (2007) Patrons, Clients, and Policies: Patterns of Democratic Accountability and Political Competition. Cambridge, UK: Cambridge University Press.

Kramon, E. (2009) Vote Buying and Political Behavior: Estimating and Explaining Vote Buying's Effect on Turnout in Kenya. Working Paper No. 114, Afrobarometer.

Milazzo, K. and Karp, J.A. (2013) Electoral Competitiveness and Candidate Behaviour in Proportional Representation Systems. Paper prepared for presentation at the Annual Conference of the American Political Science Association, August 29-September 1, Chicago, IL.

Nichter, S.C. (2008) Vote Buying or Turnout Buying? Machine Politics and the Secret Ballot. American Political Science Review 102(1):19-31.

Przeworski, A. (1986) Some Problems in the Study of the Transition to Democracy. In: G. O'Donnell, P. Schmitter, and L. Whitehead (eds) Transitions from Authoritarian Rule: Comparative Perspectives. Baltimore and London: Johns Hopkins University Press.

Schedler, A. (2013) The Politics of Uncertainty: Sustaining and Subverting Electoral Authoritarianism. Oxford: Oxford University Press.

Selb, P. and Lutz, G. (2015) Lone Fighters: Intraparty Competition, Interparty Competition, and Candidates' Vote Seeking Efforts in Open-ballot PR Elections. Electoral Studies 39: 329-337.

Takeuchi, H. (2013) Vote Buying, Village Elections, and Authoritarian Rule in Rural China: A Game-Theoretic Analysis. Journal of East Asian Studies 13: 69-105.

Ufen, A. (2006) Political Parties in Post-Suharto Indonesia: Between Politik Aliran and 'Philippinisation.' GIGA Working Paper No. 37, Hamburg: GIGA. Van de Walle, N. (2007) Meet the New Boss, Same as the Old Boss? The Evolution of Political Clientelism in Africa. In: H. Kitschelt and S. Wilkinson (eds) Patrons, Clients, and Policies: Patterns of Democratic Accountability and Political Competition. Cambridge, UK: Cambridge University Press.

\section{Articles And Reports}

Abstract Politics. (2008) Review of "Vote Buying or Turnout Buying? Machine Politics and the Secret Ballot" by Simeon Nichter. Viewed at http:/ abstractpolitics.com/2008/05/vote-buying-or-turnout-buying/. Accessed 3 April 2017. 
Open Access This chapter is licensed under the terms of the Creative Commons Attribution 4.0 International License (http://creativecommons.org/licenses/ by $/ 4.0 /)$, which permits use, sharing, adaptation, distribution and reproduction in any medium or format, as long as you give appropriate credit to the original author(s) and the source, provide a link to the Creative Commons licence and indicate if changes were made.

The images or other third party material in this chapter are included in the chapter's Creative Commons licence, unless indicated otherwise in a credit line to the material. If material is not included in the chapter's Creative Commons licence and your intended use is not permitted by statutory regulation or exceeds the permitted use, you will need to obtain permission directly from the copyright holder.

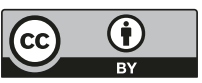

